\title{
AN ANALYSIS OF CHARACTERIZATION OF WILL TRAYNOR AND LOUISA CLARK AND THE IDEA OF COMPASSIONATE LOVE IN ME BEFORE YOU (2016)
}

\author{
Yukiko Tirzah Suhendra \\ Universitas Ma Chung, 211410014@student.machung.ac.id
}

\begin{abstract}
This review focuses on characterization and the idea of compassionate love. The writer conducted the study to explain the compassionate love seen through the characterization of the main characters in Me Before You (2016), Will Traynor and Louisa Clark. The writer uses P.A.R.T.S. characterization theory by Reams (2015) and compassionate love theory by Fromm (1995), Underwood $(2002,2009)$ and Stenberg (1986) to analyze the two main characters. The analysis uses descriptive qualitative method. The findings of the analysis show P.A.R.T.S. characterization of both main characters. There are seven characteristics of compassionate love seen through the characterization of the main characters. It is seen that Will is a stubborn and strong-willed man, yet he still has that romantic side to show his love which centers on the good of others. Louisa is seen as a persistent and sincere woman who works as Will's caregiver that later falls in love with Will and show how she can make him happy and give him freedom. The P.A.R.T.S. characterization of Will Traynor and Louisa Clark shows the kind of love which centers on the good of the other, i.e. compassionate love.
\end{abstract}

Key Terms: characterization, compassionate love, film

DOI: https://doi.org/10.33479/klausa.v3i01.155

\section{INTRODUCTION}

Me Before You was originally a novel written by British author Jojo Moyes published in 2012 and the adaptation film was released in 2016. It is actually a story of quadriplegic man, Will Traynor, who used to be a charming successful athletic person. But unfortunately, accident makes him injured then there comes a woman who works as his caregiver, Louisa Clark. Furthermore, the writer will analyze the film instead of the novel,

The writer will discuss in more depth the compassionate love depicted through the characterization of Will Traynor and Louisa Clark as the main couple in Me Before You. The story attracted the writer to analyze that it shows how compassionate love looks like in a wedding vow (The Order of Celebrating Matrimony 2016:17), i.e. keep loving in each other in good and bad times, in sickness and in health and for richer, for poorer. The story shows that a true love is love that still remains when there are differences between the relationship. Furthermore, it also aims to show how important to have compassionate love in a relationship which emphasizes the existence of love in diversity. Moreover, the writer uses characterization of P.A.R.T.S, i.e. physical description, action, reaction, thought and speech. The writer will do 
the characterization analysis preceding the explanation of how the compassionate love depicted through the two main characters characterization. The characterization must be done preceding the explanation of the depiction of the compassionate love because according to Underwood (2009:4), "Compassionate love can be seen in actions, expressions, and words,..." Therefore, characterization of P.A.R.T.S is obviously suitable to show the compassionate love depicted by the two main characters.

There are two problem statements as mentioned above on the background to analyze, i.e. characterization and the depiction of compassionate love. Therefore, the problems discussed in this paper are 1) how the characteristics of the two main characters are presented and 2) how the compassionate love is depicted through the characterization of the two main characters.

\section{P.A.R.T.S. Characterization}

According to Reams (2015:4) characterization is divided into P.A.R.T.S which are five categories, i.e. physical description, action, reaction, thought and speech. Firstly, physical description leaves an impression to audience and the audience may evaluate a character through appearance. According to Cambridge Dictionary, appearance is the way a person or thing looks to other people. Therefore, appearance happens to be the look of gender, facial expression, skin color and even fashion. Secondly, according to Reams (2015:5), "In the real world, our actions reveal who we are. In the same way, a character's actions inside a story reveal who they are." Action is considered as a concrete proof of a person's true color. In other words, people may say and think things but those things may not be that genuine as action is a concrete proof of a person's true color that action is permanent (cannot be undone). Thirdly, reaction is actually how the effect felt caused by action. Reams (2015:8) stated, "Reaction serves to develop the story and the characters at the same time. Because of this, action and reaction are very much two sides of the same coin." Fourthly, thought has a relation to point of view because what is going on people's mind may be told in some point of view. According to Reams (2015:10), "Some stories allow access to only one character's (usually the protagonist's) thoughts; some allow those of several characters. Some stories don't allow access to any character's thoughts at all." He also added it affects the reader's relationship with the character; direct access to the thoughts and inner emotions of a character allows the reader to identify with them at their most personal level. Fifthly, according to Reams (2015:12), “A character's speech or the dialogue between characters forms a medium between their actions and thoughts. How they communicate with other characters can establish not only how they feel, but also descriptors such as where they come from and their relationship with the character to whom they are speaking."

According to Cherry (2018), "Compassionate love, also called companionate love, is about intimacy, trust, commitment, and affection." Therefore, the usage both terms is considered acceptable as those two are the same. Before knowing deeper regarding compassionate love, there are several discussions on love as one of popular romance elements as well as types of love.

According to Fromm (1995:17-18), "Love is an activity, not a passive affect; it is 'standing in', not a falling for'. In the most general way, the active character of love can be 
described by stating that love is primarily giving, not receiving." Fromm (1995:19) also stated, "The most important sphere of giving, however is not that of material things, but lies in the specifically human realm. What does one person give to another? He gives of himself, of the most precious he has, he gives his life. This does not necessarily mean that he sacrifices his life for the other - but that he gives him of that which is alive in him; he gives him of his joy, of his interest, of his understanding, of his knowledge, of his humour, of his sadness - of all expressions and manifestations of that which is alive in him. In thus giving of his life, he enriches the other person, he enhances the other's sense of aliveness by enhancing his own sense of aliveness."

The definition of love by Fromm has the relation to the discussion of compassionate love later. Fromm's love explanation actually puts emphasis on the action of self-giving which enhances the feeling of aliveness of other while compassionate love has the principal of centering on the good of the other and emphasizes the enhancement of human flourishing and show the actions of self-giving and caring love that has the intention of giving full life to the other. The complete discussion of compassionate love is later discussed after the discussion of kinds of love by Stenberg.

According to Stenberg (1986), there are eight kinds of love, i.e. non love, liking, infatuation, empty love, romantic love, companionate love and fatuous love. Liking deals with true friendship where bonds, warmth, and closeness with people. It is basically related to intimacy as it has no long-term passion and commitment. Infatuated love is usually known as 'love at first sight'. It has only passion without intimacy and commitment which may lead it to disappearance. Empty love is usually the beginning love of relationship. The passion and intimacy do not yet live within, but the commitment to undergo the relationship has already been built. Romantic love deals with passion and intimacy as the couple are bonded emotionally and physically through passionate arousal. Companionate love deals with intimacy and commitment which usually lives in marriage. It has no relation to sexual or physical desire as it focuses on the friendly relationship with commitment. Fatuous love is love where the commitment is motivated by passion without a stable intimacy. Consummate love is the only complete love form in the triangle. It deals with intimacy, passion and commitment. Stenberg stated, "Without expression, even the greatest of loves can die" (1986:132). There is also possibility that consummate love may turn into companionate love once the passion is lost.

Compassionate love is also known as compassionate love. According to Underwood (2009:3), "Compassionate love is that particular kind of love that centers on the good of the other." She stated, "To be loved when it is the choice of the other, and at some emotional or physical cost, can make a special impact. In giving this kind of other-centered love one tries to truly understand and accept the conditions and state of the recipient in order to enable the recipient to become more fully alive." She also added that "altruistic love," "unconditional love," and "agape" are other terms sometimes used to describe this kind of love. Cambridge Dictionary defines compassionate as showing compassion, where compassion is a strong feeling of sympathy and sadness for the suffering or bad luck of others and a wish to help them. Therefore, compassionate love may sound synonymous with empathy, attachment, or bonding, but in fact, they are not synonymous but more into related to one another. The word 
"compassion" alone is not a synonym, as it might imply a focus limited to those who are suffering, and it can imply detachment, whereas compassionate love implies some degree of emotional engagement as appropriate, and also emphasizes the enhancement of human flourishing. According to Underwood (2009:9), "Compassionate love captures both aspects, addressing human suffering and encouraging human flourishing. In this case, the diversity in love holds the most concern that it does not only deal with human suffering but also human flourishing. According to Anand (2016:12), "Human flourishing encourages us to think about the ultimate well-being outcomes we wish to pursue and achieve." He also added, "According to the theory of human flourishing, is that what we are free and able to do, what we actually do, and our experiences are all important contributions to our overall happiness (in the broad sense)."

Compassionate love comes in a working model as a diagram. The diagram encouraged researchers to use the diagram in relation to the analysis they made. Underwood stated (2009:10), "But the model still can provide an effective tool to bring together disparate research and translate from one discipline to another, even communicating with humanities disciplines such as philosophy, theology, and the arts."

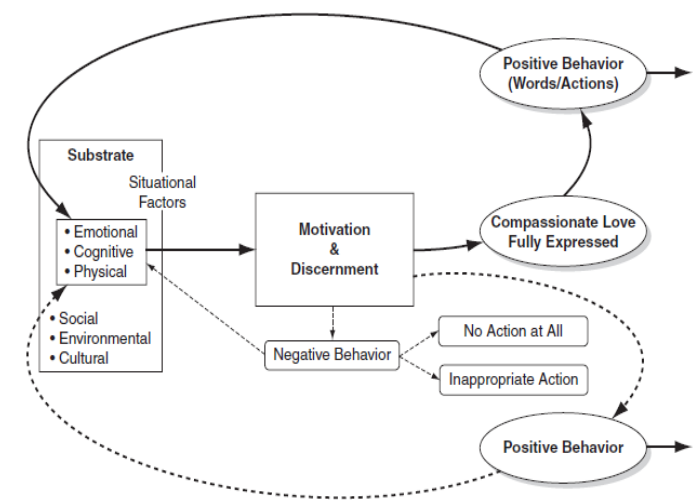

Image 2.1 Compassionate Working Model

Underwood (2002:75) stated that motivation and discernment are the internal processes involved in making decisions concerning actions. He also stated, "Compassionate love fully expressed, shown by the arrow curving up, indicates flow resulting from a balance of appropriate motives and wisdom." Then, it results in positive behaviors in a form of words and actions which then may also give impact to the internal side (emotional, cognitive, and physical) as well as the external side (social, environmental, and cultural). The downwardstraight arrow shows how motivation and discernment can result in negative behavior which can be in a form of no action and even inappropriate action. In contrast, the downward-curving arrow shows how it may result in positive behavior but for a wrong reason. For example, when someone does something hoping that they will get something in return can be considered as a selfish motive which is a contrary to the concept of compassionate love, i.e. unconditional love. Underwood (2002:77) also added, "Inner discernment could alert the person to the negative motive, however, and guide future motivation of behavior."

A compassionate love works in a way where attitudes and actions are done to give self of a person for the other. Furthermore, the word 'self' here means identifying a self-giving, 
caring love that has the intention of giving full life to the other. According to Underwood (2009:12), "The expression of compassionate love can also be affected by the specific situation and the relationship to the person being loved." People can see compassionate love through actions, expressions, and words, but its main construction consists of motivation and discernment which deal with the free choice to stretch and to give. The explanation of motivation and discernment are as follows:

\section{Motivation}

Underwood (2009:14) stated, "Motives are always mixed, so in compassionate love as expressed in daily life, there are frequently motives that obstruct orientation toward the good of the other. So many self-centered motives can get in the way, such as the need for reciprocal love and affection, the need to be accepted, guilt, fear, seeing others as an extension of one's own ego, the control of others through indebtedness, a desire to avoid confrontation, a desire to look well in the eyes of others." Motives then become a part of actions. Furthermore, in compassionate love, the motivation lays on the "centered on the good of other". Underwood also added, "The motive needs to be centered on the good of the other to count as compassionate love."

\section{Discernment}

The process of discernment is reflected in weighing things cognitively, implicitly or explicitly, to make the right decision for the other. Compassionate love fully expressed is not just good intentions, but doing what is really good for the other, or at least aiming to do so.

\section{RESEARCH METHOD}

In this research, the writer used the film Me Before You directed by Thea Sharrock based on Jojo Moyes's novel of the same title. It was released in 2016 starring Emilia Clarke as Louisa Clark and Sam Claflin as Will Traynor. The duration of the movie is 106 minutes. Furthermore, the writer used descriptive qualitative method in order to be able to provide comprehensive analysis in the form of verbal description regarding the characterization and compassionate love theories used in the analysis. The type of characterization used will be P.A.R.T.S. characterization which consisted of physical description, action, reaction, thought and speech. The writer did some steps to interpret the data. Firstly, after doing the listing P.A.R.T.S. characterization process, the writer applied the compassionate love theory stated in the second chapter for the analysis. Finally, the writer was able to conclude the compassionate love seen in the two main characters through P.A.R.T.S. characterization.

\section{FINDINGS AND DISCUSSION}

\section{P.A.R.T.S. Characterization}

Will appears as a tall white man with dark grey eyes, wavy brown hair and dimples on his cheek. At first, he has long hair and beard before he shaves. Will is a successful, charming, stubborn, strong-willed man that sees life as a perfect thing. Unfortunately, an accident breaks his perfect life and makes him injured. He is paralyzed and feels that he lives an imperfect life. Imperfect life here means he lives in pain and wants to end his life which will never get any better. He also sees that life is full of enjoyment considering that before the accident, he is an 
athletic man who likes physical activities. In fact, he cannot enjoy such things anymore after the accident. His paralysis brings his fate to meet his last caregiver, Louisa Clark. At first, he is seen as a grumpy man who is also very sarcastic. He always shows that he is sick and tired of his life. He also makes people around him know how horrible his life is. After some time, he realizes how Louisa gives the best that she can and it makes Will falls in love with her. Even though he can only move his head, he is still able to express that he does not only care of himself, but also of Louisa's life. He even grants some of Louisa's wishes, e.g. accompanying her to watch a concert, attending Louisa's birthday dinner, enjoying a holiday together. Before Will dies, he has an opportunity to write Louisa a letter. Louisa reads the letter several weeks later and she knows that Will also thinks of her life.

On the other hand, Louisa appears as a white curvy woman with wavy medium brown hair, green eyes, and rosy face. She also appears as a fashionable woman who always wear colorful clothes. Louisa is a persistent, cheerful, expressive, patient, sincere, unselfish woman. According to Will's letter, her jokes are bad and she is unable to hide every single thing she feels. Will also admits that she has possibilities to live a better life. From the very first time, Louisa shows that she never gives up in making Will happy. She greets him every day, gives him her big grin, and even brings him flowers. She keeps trying to make him happy no matter how hard it is because she knows that Will is a bit bad-tempered at first. From time to time, Louisa realizes that Will is not that annoying. Will shows his calm, sweet side which then makes Louisa falls for him. After some time, Louisa finally knows that Will tries to do assisted suicide. Knowing that surprising news, she tries to do all her best to make the rest days of Will's life more wonderful. She brings Will to watch a horse racing, to watch a concert, to celebrate Louisa's birthday at her house and even to enjoy a short holiday together. While having a short holiday together, Will and Louisa discuss about the assisted suicide. Will insists that he does not want to cancel the suicide and it makes Louisa very disappointed. But then, Louisa realizes that the assisted suicide aims to make Will free and happy. In the end, Louisa decides to accompany Will on the day of the assisted suicide to show that she does love him.

In Me Before You, the romance side in the film shows compassionate love. The compassionate love is depicted through the two main characters characterization, Louisa Clark and Will Traynor. The characterization is divided into five categories, physical description, action, reaction, thought and speech. Firstly, the physical descriptions of Will Traynor listed are Will's appearance when he shows his compassionate love. The appearance suits one of compassionate love characteristics is a desire to look well in the eyes of others. Secondly, Will's actions suits one of compassionate love characteristics, i.e. doing what is really good for the other, or at least aiming to do so. What he does show unselfish love that he does not only think of himself but he also thinks of Louisa's better future. One of his actions that obviously shows the characteristic is that he gives Louisa an amount of money to start a new beginning. Thirdly, Will's reactions suit one of compassionate love characteristics, i.e. compassionate love gives impact to the internal side (emotional, cognitive and physical). All of Will's reactions show happiness that he feels and he expresses it through smiling, grinning and giggling. Fourthly, Will's thoughts suit one of compassionate love characteristics, i.e. compassionate love centers on the good of the other. Will thinks how Louisa is a unique person (different from any other) and he also thinks of Louisa's future that she might get big chances ahead. Fifthly, Will's 
speeches show several compassionate love characteristics, i.e. emphasizing the enhancement human flourishing, giving full life to the other, doing what is really good for the other, and centered on the good of other. He compliments Louisa that she is beautiful, and he even tells her that she is his only spirit to wake up every morning. His speeches also conclude that he concerns Louisa to have a better future. He says, "I don't want you to miss out on all the things someone else could give you," and, "You need to widen your horizons, Clark. You only get one life. It's actually your duty to live it as fully as possible."

Furthermore, Louisa's characterization is also divided into five categories as same as Will's. The physical descriptions of Louisa Clark listed are Louisa's appearance when he shows his compassionate love. The appearance suits one of compassionate love characteristics is a desire to look well in the eyes of others. Louisa has a good fashion taste that she always wear colorful clothes. Secondly, Louisa's actions match several characteristics of compassionate love, i.e. focusing on the good of others, truly understanding and accepting the conditions and state of the recipient in order to enable the recipient to become more fully alive, emphasizing the enhancement of human flourishing and show the actions of self-giving, caring love that has the intention of giving full life to the other. Thirdly, Louisa's reactions match the characteristics of compassionate love, i.e. compassionate love gives impact on the internal side (emotional, cognitive and physical). Louisa's reactions show that she is worried about Will because she has compassion which simply means a strong feeling of sympathy. She also shows that she has a light heart which makes her always look cheerful and she knows she is happy because she is able to make Will feels more fully alive. Fourthly, Louisa's thoughts suit one of compassionate love characteristics, i.e. compassionate love centers on the good of the other. She thinks how horrible Will's life is and it is because she knows that she can make him happier and live a better life together with her. Fifthly, Louisa's speeches show two compassionate love characteristics, i.e. has a strong feeling of sympathy and enable the recipient to become more fully alive. She compliments Will that he looks great, and she even tells him that he gives a good impact to Louisa's life. Her speeches also conclude that she concerns Will not to end his life but continue to live that she can make him living a happier better life as seen in, "Listen, I know this is not how you would have chosen it, but I can make you happy."

\section{Compassionate Love}

The compassionate love seen in both characterizations is based on Fromm's, Underwood's and Stenberg's theories. Both Will and Louisa show that love is an activity based on Fromm's definition of love. They also demonstrate what Fromm defines as love, i.e. love is primarily giving, not receiving. Louisa's actions are mainly how she takes care of Will (feeding, helping Will to drink, accompanying Will) and giving all her life to take care of Will (spending six months being Will's caregiver). Will may not be able to show the act of giving physically, but at the end, he is willing to give an amount of money for Louisa to start a new life (as seen in Will's action). Another Fromm's discussion of love is giving what is alive in self, e.g. the joy, the interest, the understanding, the humor and the sadness. It simply means giving all the alive things in self. Both Will and Louisa give the joy, interest, understanding, humor, sadness and even anger to each other. Those things are the things which make others' sense of aliveness enhanced. This can also be related to human flourishing which basically means freedom and 
happiness. Will gives what makes Louisa feel free and happy, i.e. he gives all his love (as seen in P.A.R.T.S characterization), provides things which should buy Louisa freedom and happiness as well as encourages her to realize that life happens once that she has to live it boldly (as seen in Will's action and speech). Louisa also gives what makes Will feel free and happy, i.e. she gives all her love, accepts and understands Will's decision to end everything because it what makes him free and happy that he no longer suffers. At first, Louisa thinks that Will is selfish that he wants to end his life but she later realizes and understands as well as accept that Will does not only think of himself to be free and happy but also think of Louisa to start a new beginning and still get the chance to enjoy all the things someone else can give her.

Compassionate love is fully expressed when the motives are appropriate. As mentioned before in Chapter 2, motives then become a part of actions that in compassionate love, the motivation lays on the "centered on the good of other". Both Will and Louisa show how their motives are appropriate, i.e. do not only think of themselves, but also think of others'. This motive then turns into discernment which full of consideration to make the right decision. Will's right decision can be seen that he does not cancel his assisted suicide even though Louisa can make him happy. The only thing he considers is that he does not want Louisa to miss out all of the things someone else can give her. Furthermore, Louisa's right decision can be seen that she accepts and understand Will's decision because she knows it is the only thing that makes him happy and free.

Underwood's discussion regarding the internal process happened before expressing compassionate love is also shown. They also give impact to each other's internal side (emotional, cognitive, and physical). In emotional side, both Will and Louisa feel the compassionate love they share to each other. In cognitive side, both Will and Louisa pay attention to each other so that they understand each other as well as think then decide things. In physical side, they show actions which they think are important for the sake of each other's happiness and freedom. In Underwood's discussion, there is also an explanation how compassionate love works. It works basically when one's attitudes and actions aim to give self of a person for the other. Furthermore, the word 'self' here means identifying a self-giving, caring love that has the intention of giving full life to the other. Both Will and Louisa's actions show how they share a self-giving and caring love which result in giving full life to other. They do what is really good for each other. The word 'good' here means what is really good not only for the present, but also for the future.

The last discussion of compassionate love comes from Stenberg's explanation. The idea of compassionate love from him lays on the intimacy and commitment which is basically called as friendly relationship. Both Will and Louisa show how they build their intimacy everyday for six months. Louisa shows that she has the commitment to stay with Will, to take care of him as well as shower him with compassionate love. In addition, Will also shows that he has the commitment not to stay forever with Louisa that he knows that Louisa deserves to meet other wonderful chances.

There are seven characteristics of compassionate love seen through the characterization of the main characters, i.e. desire to look well in the eyes of others, doing what is really good for the other or at least aiming to do so, compassionate love gives impact to the internal side 
(emotional, cognitive and physical), centers on the good of the other, truly understand and accept the conditions and state of the recipient in order to enable the recipient to become more fully alive, emphasizes the enhancement of human flourishing and show the actions of selfgiving and caring love that has the intention of giving full life to the other, and has a strong feeling of sympathy and enable the recipient to become more fully alive. It is also obviously proven that compassionate love can be seen through actions, expressions and words or in other words, it can also be seen through characterizations. Therefore, as a conclusion, the P.A.R.T.S. characterization shows the compassionate love based on Fromm, Underwood and Stenberg theories seen in Will Traynor and Louisa Clark.

\section{CONCLUSION}

Me Before You movie tells a love story between Will Traynor, a quadriplegic man, and Lousa Clark, his caregiver. The story attracted the writer to analyze the love that exists in their relationship, i.e. compassionate love. Therefore, the writer uses characterization of P.A.R.T.S to help the discuss the compassionate love seen through the characterization of the main characters.

The principle of P.A.R.T.S proposes the five areas of characterization, i.e. physical description, action, reaction, thought and speech. The listed characterizations of each category are presented along with its time location in the film. As a result, Will appears as a successful, charming, stubborn, strong-willed and bad-tempered man who lives a perfect life. Unfortunately, an accident brings him to live a life full of pain and sorrow. His paralysis makes him meet his last caregiver, Louisa Clark. At last, he is able to fall in love with Louisa and shows that he does not only have a grumpy side but also a sweet side. As for Louisa, she appears as a persistent, cheerful, expressive, patient, sincere and unselfish woman. She works as Will's caregiver before she knows that Will tries to commit an assisted suicide. She makes the remaining days of Will's life more wonderful and finally realizes that she falls in love with him. She may be angered to know that Will wants to end his life. In the end, she realizes that she cannot resist what makes Will free and happy.

The compassionate love seen in Will and Louisa's characterizations is based on Fromm's, Underwood's and Stenberg's theories. Both characters reflect Fromm's idea that love is an activity that is primarily giving, not receiving. The characterizations also show Underwood's idea that compassionate love is a self-giving and caring love that results in giving full life to other. In addition, the characterizations also show Stenberg's idea that compassionate love lies in the intimacy and commitment that is basically called friendly relationship.

The P.A.R.T.S analysis of characterization is done prior to the discussion of compassionate love in order to help the writer discuss the compassionate love later. The choice of the particular characterization suits one idea of compassionate love, i.e. compassionate love can be seen in actions, expressions and words. Therefore, the five categories of the characterization has the relation to the compassionate love idea. As a result, there are seven characteristics of compassionate love seen in both Will and Louisa characterizations. In conclusion, both Will and Louisa's P.A.R.T.S characterization shows the compassionate love that exist in their relationship. 
The writer found some recent studies that have been mentioned in Chapter 2. The recent studies are in the field of linguistics, especially sociolinguistics. Therefore, the writer suggests that further researchers may try analyzing either the film or novel using literary criticism such as psychoanalytic criticism and feminism. An ecranisation analysis can also be considered to analyze both novel and film. Me Before You also has a sequel to it, After You (2015). Therefore, the writer also suggests further researchers to analyze After You considering that the novel is relatively new. For instance, a further research of Me Before You using a theory of romance in popular cinema by Todd (2014) also suggested.

The writer suggests that further researchers analyze using P.A.R.T.S analysis of characterization and Compassionate Love theory with different literary works. Furthermore, the writer hopes that more researchers will be interested in analying values except love, e.g. kindness, loyalty and boldness. In conclusion, a deeper analysis of Me Before You novel and film along with its sequel After You using other theories is suggested.

\section{REFERENCES}

Anand, P. (2016). Happiness Explained: What Human Flourishing is and What We Can Do to Promote It. Oxford University Press. Oxford.

Appearance. n.d., Accessed 5 July 2018 at: https://dictionary.cambridge.org/dictionary/english/appearance

Cherry, K. 2018. Compassionate and Passionate Love. Accessed 1 March 2018 at: www.verywellmind.com/compassionate-and-passionate-love-2795338

Compassionate. $\quad$ n.d., Accessed 14 April 2018 at: https://dictionary.cambridge.org/dictionary/english/compassionate

Fehr, B., Sprecher, S., Underwood LG. 2009. The Science of Compassionate Love: Theory, Research, and Applications. Blackwell Publishing Ltd. United Kingdom.

Fromm, E. (1995). The Art of Loving. Thorsons. London

International Commission on English in the Liturgy Corporation. (2013). The Order of Celebrating Matrimony: English Translation According to the Second Typical Edition. Liturgical Press. Minnesota.

Post, S.G. et al., (2002). Altruism \& Altruistic Love: Science, Philosophy, \& Religion in Dialogue. Oxford University Press. New York.

Reams, J. (2015). Characterization in Fiction. Honors Thesis. Texas State University. Texas.

Sternberg, R.J. (1986). “A Triangular Theory of Love.” Psychological Review, 93 (2), 119-135. Available at: https://pdfs.semanticscholar.ord/7816/6e46a82323730f2fe683b855466e863b445d.pdf [Accessed 15 April 2018].

16 | An Analysis of Characterization of Will Traynor and Louisa Clark 
ISSN: $2301-4822(p)$

DOI: 10.33479/klausa.v0301

\section{A 4 a Bahasa, dan Sastra}

\section{Editorial Team}

Editor-in-Chief

Journal Manager

Editors

Reviewers

Publisher

Address

Frequency
: Dr. Daniel Ginting

: Wawan Eko Yulianto, Ph.D.

: $\quad$ Prof. Dr. Patrisius I. Djiwandono

Lilis Lestari Wilujeng, M.Hum.

: $\quad$ F.X Dono Sunardi, M.A.

Dhatu Sitaresmi, MTCSOL.

Anggrah Diah Arlinda, MTCSOL.

Prof. E Sadtono, Ph.D.

Yohanna Nirmalasari, S.Pd., M.Pd.

Prof. A. Effendi Kadarisman, Ph.D.

Sisilia Halim, Ph.D.

Dr. Mundi Rahayu

Dr. Ross Wood

Dr. Leticia Araceli Salas Serrano

: Faculty of Language and Arts

Universitsas Ma Chung

: The Faculty of Language and Arts

Ma Chung University

Villa Puncak Tidar N-01 (65151)

Malang, East Java, Indonesia

Email: jurnal.klausa@machung.ac.id

: $\quad$ Twice a year 